\title{
A Model of Village Government System Based on System Thinking A Study in Kairane Village, Indonesia
}

\author{
Ike Wanusmawatie, \\ Department of Public Administration \\ Brawijaya University \\ Malang, Indonesia \\ ikew@ub.ac.id \\ Bambang Supriyono \\ Department of Public Administration \\ Brawijaya University \\ Malang, Indonesia
}

\author{
Luqman Hakim \\ Departement of Public Administration \\ Brawijaya University \\ Malang, Indonesia \\ MR.Khairul Muluk \\ Departement of Public Administration \\ Brawijaya University \\ Malang City, Indonesia \\ mrkhairulmuluk@gmail.com
}

\begin{abstract}
The purpose of this study was to construct a model of village government performance system in order to realize the community prosperity. This research used system thinking approach and dynamic system as tool analysis. Based on the research results indicates that village government performance is not optimal currently because of the low level of public services and dependence to central government grants. It is resulting in artificial poverty. Furthermore, the basic structure of village government in Kairane village as a system consist of 14 sub system and interact each other such as public service, complaint, community empowering, poverty, support of local government, support of central government, community trust, support of indigenous community, role of NGO, support of village apparatus, support of village council, support of facilities and infrastructure, and support of village finance. Among those elements is leverage that is able to maximize the performance of village government as a system.
\end{abstract}

Keywords: dynamic system; rural; public administration; poverty

\section{INTRODUCTION}

The percentage of poor people in urban areas in September 2016 was 7,73 percent, while in rural areas 13.96 percent [1]. This data could be many interpreted such us ineffectiveness of village government, or poverty. In addition, considering the majority of Indonesia's population living in the rural areas, it is important to conduct research related to the performance of village government in order to achieve community prosperity.

Many previous researches on village has been done before with different purpose. Indonesian Public Administration Agency/LAN [2], focus on improvement of village government capacity while BAPPENAS [3], as National Development Planning Agency focus on village development. The same object study but differences in focus and analysis tool imply to problem-solving. Nevertheless there must be a connection between one element with another to form a cycle. Thus it can be said that every element able to be causes and effect at once. This forms complexity.
Systems thinking offer a new way of thinking based on the primacy of the whole and of relationships [4] In the systems thinking perspective, all the components that make up the complexity should be taken into account. Thus, it takes an understanding of the complexity of the components that interrelationship and processes of village government system. This is often rarely understood. Therefore, it takes the problem recognition and stakeholders mapping to understand the problem and provide the desired situation. In addition to see the current conditions of village government performance. Thus, construct a basic structure based on reality as a model It is important to optimize the performance of village government system in order to achieve community prosperity. The significant of study is able to give alternative scenario to make policy on village.

\section{RESEARCH METHOD}

This research uses systems thinking approach. Systems thinking is conceptual framework, a body of knowledge and tools to make the full patterns clearer, and to help us see how to change them effectively [5]. The performance of village government in order to achieve prosperity community is not a simple problem that is easily solved. The operational definition of village government performance is result from public services activity and village community empowering.

The performance as an object study and system too, while the elements call sub systems consist i.e.: public services, complaint, community empowering, poverty, support of local government, support of central government, role of NGO, role of missionary, community trust, indigenous community, support of village apparatus, support of village council, support of facility, support of finance, farming, income, basic need services, and support of infrastructure. All those sub sub sytems interact each other and making feedback loop such as balancing or reinforcing. Furthermore, forming behavior over time. The system need limitation to cut many sub systems. Border is limitation of system. The border of this system is Kairane village environment. Last but not the least the goal of this system is to achive prosperity community

Corresponding author: Ike Wanusmawati 
Type of research is combine quantitative and qualitative paradigm based on "the dominant-less dominant design" [6] . Research location in Kairane village Kupang district East Nusa Tenggara. Data collection technique are in-depth interviews with villager in Kairane, village head, village secretary, other apparatus dan village council. In addition, local officer from BPMPD (agency of community empowering and village Government), village government division of kupang district secretariat and secretary of Amabi Oefeto sub district. Focus group discussions, also conducted with the villagers, Kairane village government such as chief of village council call $B P D$ (Badan Permusyawaratan Desa), chief of hamlet, PKK as local village organization for woman, Bengkel APPeK as local NGO and Policeman who fostering public security and order in Kairane village call Bhabinkamtibmas. Tool analysis using dynamic system [7] consist of five-stage i.e. (1) Problem recognition; (2) Problem understanding \& system description; (3) Qualitative analysis; (4) Simulation Modelling (special computer simulation languages by Powers software) and (5) Policy Testing and Design. This research is actually designed up to five stages, but technical constraints make it cannot be displayed, so it only stops at the 4th stage. Hopefully this research can be continued again until the last stage. Tend to use indigenous rule rather than positive law.

\section{RESULT AND DISCUSSION}

Based on analysis setting location, Kairane village located in the middle of industrial plant forest belong to central government and has limited infrastructure. This village is part of the administrative area of Amabi oefeto sub district and Kupang district. The dominant characteristic of the villager is relying on agricultural products, plantations and livestock, especially cattle. Nature of kinship, cooperation and honesty villagers are strong. Reject the outsider influences that are not appropiate with the indigenous community and local wisdom, except they bring positive influence for their prosperity. On the other hand, the community tend to use indigenous rule rather than positive law.

Kairane village is a forest village. It has two dominant institutional structures, namely indigenous community and village government. This village is the result of the formation of the government called by the term new style village (desa gaya baru). It is quite different with the characteristic of javanese village because original came from community. In social life, the role of indigenous communities is very strong and able to influence the village government decisions related to the performance of village government, especially in the field of public services and community empowering. Likewise, with people who have high confidence with indigenous rules issued by indigenous communities. Characteristic of village is similar to the Gemeinschaft as conveyed by Tonnies, translated by Loomis [8] to "Community and Society". Another side, village government as an organization consisting of village head, village secretary, apparatus implementer, assisted by head of hamlet and village council as a partner to control of the implementation of village government. Kairane similar with local democracy model principal. what is described above is an overview of the Kairane.
Here this is the current condition of village government performance and the constructed model:

\section{A. The Performance of Kairane Village Government Currently}

The Performance of village government system to achieve community prosperity consist of two main inflow and outflow. There are public service activity and community empowering as inflow while complaint and poverty as outflow. Every stream has different feedback loop such as reinforcing, balancing or $\mathrm{S}$ curve. The current of Kairane village government performance as follows:

- Input: support of central government; local government support, role of ngo, community trust, support of indigenous community, village apparatus, village council, facilities, village finance and infrastructure.

- Process: giving public services such as local administrative and services but not able to empower village community itself and fulfill the basic need. Local and central government and has dominant role for empowering. Actually, local government has role to support public services on basic need, but the fact is less of local government support stop in sub district.

- Output: the villager accepts all the type of local administrative \& services, except services that requiring of local government support. Basic need services especially basic education required more attention from upper government because this is important for community knowledge are enabled to become one of the causes of poverty. Education is another major service where issues of the effects of poverty are important, particularly interms of achievement [9]. Greenstein, Gentilini \& Sumner [10], also said that education discourages coordinated needed sustainable improvement. Back to the research of result in kairane on community empowering: the target group accept all empowering program from local as revolving fund and central government as rural community empowering national program call $P N P M$ including NGO giving farming assistance on elderly (lansia) garden. This garden empowering

- Outcome: local administrative \& services are satisfied except basic need services because requiring local government support, the villager tend to dependent with local and central government grants as the way to alleviate poverty. Even though as statistical the poor people more less than before, but other social problem comes. It is dependent mental. They prefer being recorded as poor er than non-poor, because if they are honest then aid will be withdrawn and they cannot enjoy it anymore.

\section{B. A model of Village Government System based on Systems Thinking}

The Performance of Kairane village government system to achieve community prosperity has 14 sub systems. There is sub system of support of central government; local government support, role of NGO, public service, complain, community empowering, poverty, support of community trust, support of indigenous community, support of village apparatus, support of 
village council, support of facilities, support of finance and, support of infrastructure.

\section{1) Dynamic Causal Loop Diagram}

Dynamic causal loop diagram is the dynamic structure of the relationships affect each other and interact between each element or sub system. dynamic meaning, because the structure is more flexible not detail. it can be developed based on facts in the field that often differ from one location to another even between one event with others. Those elements interact and has inter relation. It calls causal loop diagram. It is provide a framework for seeing interrelationships rather than things, for seeing patterns of change rather than snapshot ${ }^{[11]}$. This causal loop diagram prepared using the entity / state / transition method. This method identifies all entities that exist in a system and then mapping the transition from a state entity to another condition. Selection of this method is based on the excess in describing the following flow type and strength which control the flow. There are several steps involved in using this method. First, identify all entities or actors that are within the scope of the problem. Second, identify the condition (state) that allows for every existing entity. Third, identify the flow that can cause changes in the condition. Fourth, check the connection between the flow, including the possibility of delay time. Fifth, identify the controlling flow that affect the system. Sixth, identify the effect of the information and action influences of the flow control above.

Those interaction form feedback loop, and then each sub systems have behavior over time (BOT). Based on feedback loop, it can determine the BOT, of course after running the data. The type of BOT are exponential growth, goal seeking, collapse and decay. Here is a depiction of dynamic causal loop diagram

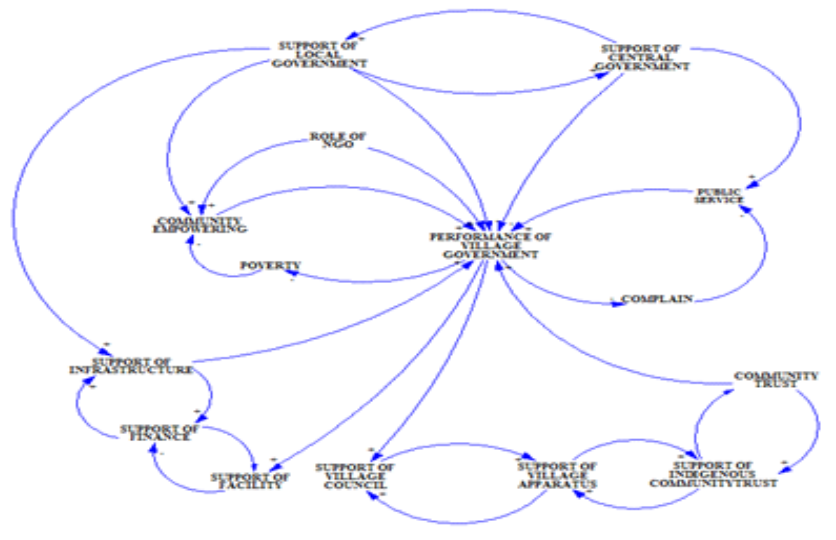

Fig 1. Dynamic of causal loop diagram of Kairane village government performance

\section{2) Detail Complexity of Causal Loop Diagram}

Based on the figure 2, the level of public services can be optimized with local government support and supporting from the role of the village secretaries (civil servant status). The level of self-reliance can be optimized with the existing program (revolving funds) accompanied by substance of grant. assistance rather than administrative that has been done. Income optimized through empowerment programs and improvements in village infrastructure to reduce dependent mental to central government grants.

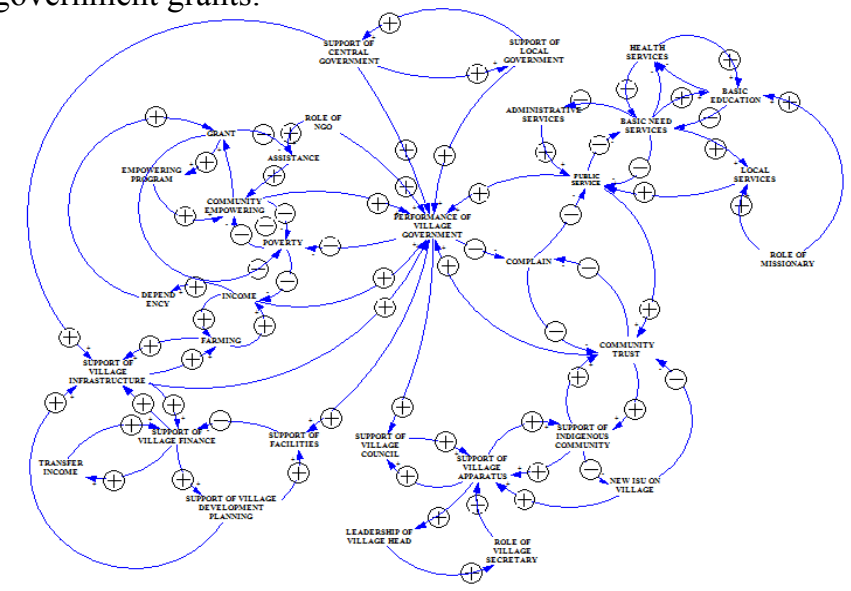

Fig 2. Detail complexity of close loop diagram of village government performance system.

All sub system on reality model above appropriate with previous researches will be like following the Figure 3:

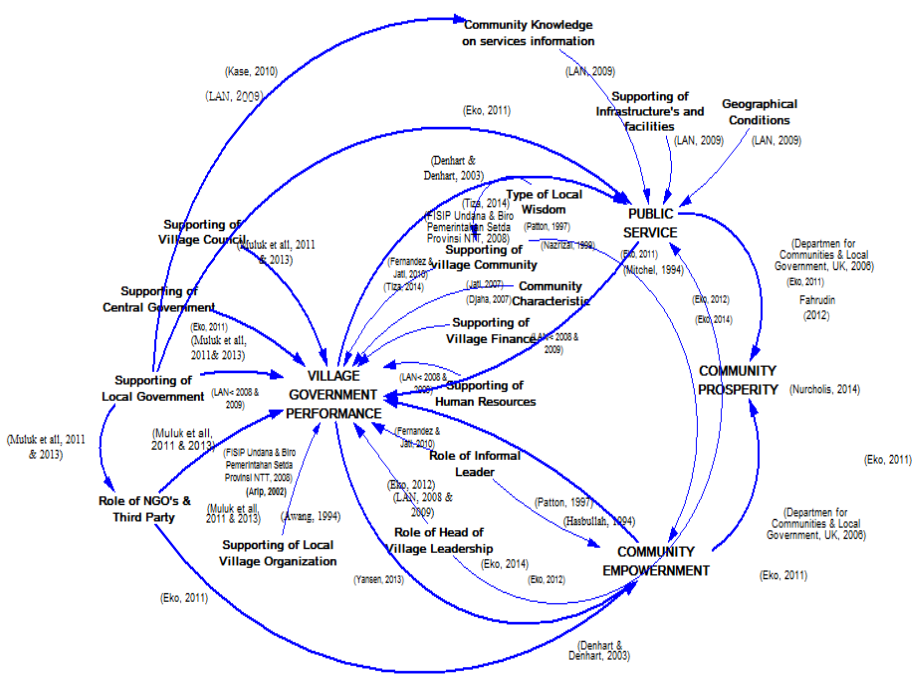

Fig 3. Causal loop diagram on village government system based on previous studies [12]

The previous studies have differences in the methods and outcomes generated by the researches. The result of this research with dynamic system method produce output in the form of policy scenario to optimize the performance of village government. The scenario is based on leverage derived from one sub system that has great value to the performance of village government, with a little treatment can improve performance.

This research has limitations mainly in the fifth stage of design and simulation policy. This stage has not been completed, so leverage cannot be ascertained its existence, but can be assumed by looking at the number of inflow and outflow to the one of the sub system in close loop diagram above. 


\section{CONCLUSION}

A model of village government system has three types, i.e. first, theoretical model, existing model and recommended model. All model based on system thinking, with causal loop characteristic. Theoretical model compiled based on previous study while existing model based on problem recognition and understanding from reality in research location, last recommended model is existing model with new treatment.

Inland villages tend to experience limited infrastructure and access to information, so that public services are mainly basic needs are not optimal and cause culturally poverty. The lack of understanding of the structure on poverty problem will lead to new problems, namely dependence such as happen in Kairane village. Village government as a system cannot optimize its performance without support from supra structure i.e. local and central government also third-party support. This reinforces the results of previous studies [13][14][15] and local government theory that village government is a sub-system of local government[16][17].

The scenario of optimizing the performance of Kairane village government in order to realize the welfare of the village community can be done in the following way: first improving the degree of public services through the role of village secretaries with status of civil servant and local government support; second, increasing the self-reliance of rural communities through intensive revolving fund and assistance programs related to the problems faced by villagers; third, increasing the development of village infrastructure. It can be a increasing the community income through the activities of general agriculture (cultivating and breeding) and access information mainly related to education.

\section{ACKNOWLEDGMENT}

The author would like to thank to Prof. Dr. Bambang Supriyono, Dr. Drs. Luqman Hakim, M.Sc and Dr. MR Khairul Muluk, M.Si for supporting this research.

\section{REFERENCES}

[1] Indonesian Statistic Center Bureau/BPS, Monthly report: Economic Social Data, edition 89, October, Jakarta, 2017, pp 150.

[2] Public Administration Agency, "Executive summary: Review on capacity incresing of village government", Jakarta, 2013, pp 1-5.

[3] Directorate of Evaluation on Sectoral Development Performance Ministry of National Development Planning / BAPPENAS 2011, "Final Report: Evaluation of rural development in the context of community welfare improvement", Jakarta, 2011, pp 1-134.

[4] K. E Maani \& R.Y Cavana, "Systems thinking and modelling: understanding change and complexity, Prentice hall, Pearson Education. New Zealand, 2000, pp 2-11

[5] P.Senge, "The Fifth Discipline: The art and practise of the learning organization., Doubleday Dell Publishing Group, Inc. 1540 Broadway, New York, 1990, pp 10.

[6] J. W. Creswell, Research Design Qualitative and Quantitative. Approaches. Sage Publications. London 1994., pp 179

[7] R.G Coyle, "System dynamics modelling: a practical approach. Chapman \& Hall, London, 1996, p. 11..

[8] P. Loomis, Charles, editor, "Community and Society", Gemeinschaft und Gesellschaft by Ferdinand Tonnies, Dover Publication, New York, 2002.
[9] G. Bramley and D. Watkins, The public service costs of child poverty joseph rowntree foundation, 2008, pp 4

[10] J. Greenstein, U. Gentilini,\& A. Sumner, "National or international poverty lines or both? Setting goals for income poverty after 2015, Journal of Human Development and Capabilities, 2014 Vol. 15, Nos. 2-3, pp 132-146

[11] Ref [5] pp 68

[12] Previous study:

- J.V. Denhardt \& R.B. Denhardt, 2003.The New Public Service: Serving, Not Steering. (New York: M.E.Sharpe, 2004).

- Department for Communities and Local Government, 2006. Strong and Prosperous Communities.The Local Government White Paper. Volume 1. www.communities.gov.uk

- E. Sutoro. Editor. "Voice of Residents Voice of Development A RPJM-Village Study in East Sumba Regency. Cooperation between Australia Indonesia Partnership, East Sumba Regency Government and Koppesda".. (Suara Warga Suara Pembangunan Sebuah Studi RPJM-Desa di Kabupaten Sumba Timur. Kerjasama Australia Indonesia Partnership, Pemerintah Kabupaten Sumba Timur, dan Koppesda). 2011.

- E.Sutoro. "Village Change in Eastern Indonesia. Tematic Paper. Stocktake: Lessons Learned from the ACCESS Phase II Program on Village Self-Reliance and Poverty Reduction in Indonesia. Australian Community Development and Civil Society Strengthening Scheme (ACCESS) Phase II. Autralian AID and IRE Yogyakarta". (Perubahan Desa di Indonesia Timur. Tematic Paper. Stocktake: Pembelajaran dari Program ACCESS Tahap II Terhadap Kemandirian Desa dan Penanggulangan Kemiskinan di Indonesia. Australian Community Development and Civil Society Strengthening Scheme (ACCESS) Phase II. Autralian AID dan IRE Yogyakarta) 2012.

- E. Sutoro. "Binding Desa Membangun Indonesia. Forum for Village Renewal Development (FPPD). Colaboration between Australian Community Developmenth and Civil Society Strhenghtening Schemes (ACCESS) Phase II and Indipth. First Printed: February 2014". (Binding Desa Membangun Indonesia. Forum Pengembangan Pembaharuan Desa (FPPD). Colaboration between Australian Community Developmenth and Civil Society Strhenghtening Schemes (ACCESS) Phase II and Indipth. Cetakan Pertama : Februari 2014. Yogjakarta).2014.

- A. Fahrozi, "Good Governance In Implementing Village Governance.” (Qualitative Descriptive Study in Panjangrejo Village, Pundong District, Bantul District, Yogyakarta Special Province Year 2008). Essay. Department of Government Science Faculty of Social and Political Sciences Muhammadiyah University of Yogyakarta. Good Governance Dalam Penyelenggaraan Pemerintahan Desa. Unpublished, 2009.

- A. Fahrudin, Introduction to Social Welfare Science. (Pengantar Ilmu Kesejahteraan Sosial). Refika Aditama. Bandung.

- Fitha, Dwi, Bony, Ayu, "Effectiveness of Nagari Government Organization In Koto Vii Sub-District Sijunjung. Thesis. Graduate program. Andalas University. West Sumatra" (Efektivitas Organisasi Pemerintah Nagari Di Kecamatan Koto Vii Kabupaten Sijunjung.Tesis. Program Pasca Sarjana. Universitas Andalas. Sumatera Barat.) http://pasca.unand.ac.id/id/wp-. Unpublished content/uploads/2011/09/ringkasan.pdf. downloaded at Thursday , 23 Sepetember 2014, 2012.

- Fernandez, and Jati. “ Attitudes of Customary Community of Keba Bai Pito to Village Government Organizations According to Government Regulation Number 72 Year 2005 (Case Study in Ile Mandiri Subdistrict of East Flores Regency). Journal of Public Administration Vol 9, No. October 1, 2010" (Sikap Komunitas Pranata Adat Keba Bai Pito Terhadap Organisasi Pemerintah Desa Menurut Peraturan Pemerintah Nomor 72 Tahun 2005 (Studi Kasus di Kecamatan Ile Mandiri Kabupaten Flores Timur). Jurnal Administrasi Publik Vol 9, No. 1 Oktober 2010. Diterbitkan Jurusan Administrasi Negara FISIP Universitas Nusa Cendana Kupang NTT). 2010.

- A. Furqani, "Management of Village Finance in Achieving Good Governance. (Study on the Village Government of Kalimo'ok Kaliumen District of Sumenep Regency). Thesis. Master of Accounting Study Program. Postgraduate Program of National 
Development University "Veteran" East Java Surabaya". (Pengelolaan Keuangan Desa Dalam Mewujudkan Good Governance. (Studi Pada Pemerintahan Desa Kalimo'ok Kec. Kalianget Kab. Sumenep). Tesis. Program Studi Magister Akutansi. Program Pascasarjana Universitas Pembangunan Nasional "Veteran" Jawa Timur Surabaya.), 2011.

- P. Kase, "Transparency in the Implementation of Poor Health Services Policy. Journal of Public Administration Volume 9No. 1. October 2010. Department of Science State Administration FISIP University Nusa Cendana Kupang-NTT" (Transparansi Dalam Implementasi Kebijakan Pelayanan Kesehatan Masyarakat Miskin. Jurnal Administrasi Publik Volume 9No. 1. Oktober 2010. Jurusan Ilmu Administrasi Negara FISIP Universitas Nusa Cendana kupangNTT). 2010.

- Nurcholis,Hanif et.al. "Village Government: Counterfeit Government Unit in the State System of the Republic of Indonesia" (Pemerintahan Desa (Village Governement): Unit Pemerintahan Palsu Dalam Sistem Tata Negara Republik Indonesia) . 2014.

- H. Nurcholis, "Critical Note Against Law Number 6 Year 2014 About Villages. Proceeding SIMNAS to 4 Association of State Administration Scientists (ASIAN) with Theme of Village Autonomy in Context Law No 6/2014 on Village ("Catatan Kritis Terhadap
Undang-Undang Nomor 6 Tahun 2014 Tentang Desa. Proceeding SIMNAS ke 4 Asosiasi Ilmuwan Administrasi Negara (ASIAN) dengan Tema Otonomi Desa Dalam Konteks UU No 6?2014 Tentang Desa. 2014.

[13] G. Soeharto, D. Muktiyo. Widodo, and Pavito, "The Development of Village Autonomy using Decentralization. Southeast Asian Journal of Social and Political Issues", Volume 1, Number 3,2013, pp 330-343. Faculty of Social and Political Sciences University of Sebelas Maret.

[14] Muluk, M.R Khairul, Wanusmawatie, Ike and Said, Moch. "Developing Systemic Model for Indonesian Village (Desa)" Government. Journal of Basic and Applied Scientific Research No.3 Vol. 2. Text Road Publication, 2013. pp 202-208..

[15] B. Chekoway, "Neighborhood needs and organizational resources: new lessons from detroit”. Pcma working crso working paper,1989, pp 1-32

[16] B.C Smith, Decentralization: The Territorial Dimension of the State G. Allen \& Unwin, 1985 pp 1-227.

[17] Burn, Danny, hambletton, Hugget, "The Politics of Decentralization. Revitalising Local Democracy". MACMILLAN Press LTD. Houndmills, Basingstoke, Hampshire RG 212XS and London, 1994,, pp 1-324 